\title{
RUBIES AND FANCY-COLOR SAPPHIRES FROM NEPAL
}

\author{
By Christopher P. Smith, Edward J. Gublein, Allen M. Bassett,
} and Mache N. Manandhar

Gem-quality rubies and fancy-color sapphires have been recovered from dolomite marble lenses located high in the Himalayan mountains of east-central Nepal (Ganesh Himal). First discovered in the early 1980s, these deposits have had only limited and sporadic production because of their isolated locations, high altitudes, and harsh seasonal weather conditions. The precise locations and geology of the two bestknown deposits are described. In addition, 27 polished samples and 19 rough crystals and mineral specimens were thoroughly investigated to document their gemological characteristics and crystal morphology. The most distinctive internal features are their color-zoning characteristics, various cloudlike and other patterns, as well as a wide variety of mineral inclusions, some of which have not been seen in rubies from other sources.

\section{ABOUT THE AUTHOR \\ Mr. Smith is a research gemologist residing in Lucerne, Switzerland. Dr. Gübelin is a gemologist and co-author of the Photoatlas of Inclusions in Gemstones and various other books and publica- tions. Dr. Bassett is retired professor of geology, California State University, San Diego, and technical director of Himalayan Gems Nepal; he resides much of the year in Katmandu, Nepal. Mr. Manandhar is general director of Himalayan Gems Nepal, Katmandu, Nepal. \\ Gems \& Gemology, Vol. 33, No. 1, pp. 24-41 \\ (C) 1997 Gemological Institute of America}

\begin{abstract}
J epal is a small mountainous country situated along the Himalayan mountain chain in southern Asia.Landlocked by Tibet (China) to the north and India to the east, south, and west, Nepal's surface area covers only 140,000 $\mathrm{km}^{2}$; it has approximately 20 million inhabitants. Southern Nepal is the birthplace, more than 2,500 years ago, of Siddartha Gautama, the founder of Buddhism. For many centuries, Nepal was closed off from the rest of the world. Only since it emerged from a feudal state in 1950, have the minerals and gemstones of Nepal begun to enter the world economy. Although Nepal has a reigning monarch, a multiparty democracy was established in 1990.

Most widely recognized for having the highest elevation of any country in the world, Nepal is the home of Mount Everest $(8,848 \mathrm{~m} / 29,028$ feet above sea level). In all, seven of the eight highest peaks in the world can be found in this country's rugged terrain.

Although Nepal has limited industrial development and relatively meager mineral wealth, it is blessed with a broad range of gem minerals that includes tourmaline, beryl, garnet, quartz, spinel, danburite, hambergite, kyanite, apatite, sodalite, zircon, sphalerite, epidote, diopside, iolite, feldspar, pyrite, hematite, andalusite, lepidolite, and corundum (Bassett, 1979; 1984; 1985a and b; 1987). Gems have been recovered in Nepal since 1934, when tourmaline and aquamarine were first discovered there (Bassett, 1979). However, not until the early 1980s did rubies and sapphires begin to appear (figure 1).

As the story was told to authors AMB and MNM, goat-herders of the Tamang ethnic group first spotted red crystals in 1981, high in the Ganesh Himal massif of the Dhading District in east-central Nepal. These stones were brought to the capital city (Katmandu) to sell for shop displays, where they were identified as rubies. The first official report of corundum in Nepal was made by Baba (1982), who erroneously described
\end{abstract}


Figure 1. Since the early 1980s, rubies and fancycolor sapphires have been recovered in the

Himalaya Mountains of east-central Nepal. The Nepalese rubies shown here range from 0.50 to $2.50 \mathrm{ct}$. Jewelry courtesy of the Gold Rush,

Northridge, California; photo by Shane F. McClure.

ruby/corundum coming from the Taplejung District, in eastern Nepal. Soon after, however, it was determined that the source was actually in the Ganesh Himal (Dhading District), and many staked claims there, hoping to make their fortunes. For the most part, however, these earlier miners lacked any understanding of gemstone recovery methods or of the geology and challenging topography of the mountainous region, so these early efforts met with limited success. It was not until 1984 that one of the authors (AMB) made the first geologic study of the corundum-producing region at Ganesh Himal (Bassett, 1984). After concluding this investigation, AMB joined with MNM to found Himalayan Gems Nepal, which acquired the leases to the two most commercially viable claims, known as Chumar and Ruyil. Himalayan Gems Nepal began officially recognized mining activities during 1985 . They also set up a cutting factory to bring these rubies and fancy-color sapphires to the gem and jewelry markets. Several other parties also mined unofficially in the surrounding region.
None of these mining ventures lasted long, however, because of the isolated locations, harsh weather conditions, and difficulties encountered in efforts to develop larger-scale mining. All of the claims were eventually abandoned by their owners. Today, local Tamang farmers continue rudimentary mining; they bring their production to Katmandu for sale and distribution. As a result, throughout the mid- to late 1980s and early 1990s, the production of gem-quality rubies and fancy-color sapphires was sporadic. Although Himalayan Gems Nepal also ceased active mining after about two years, they continue to buy gems from the local farmers and cut them in their factory.

Since mid-1996, two other deposits-Shelghar and Shongla-have produced corundum that is comparable in quantity and quality to Chumar and Ruyil. During studies in 1985, AMB determined that the geology of these two deposits is identical to that of Chumar. Besides these four producing deposits, two others (Pola and Sublay) are known to have potentially significant amounts of corundum, 


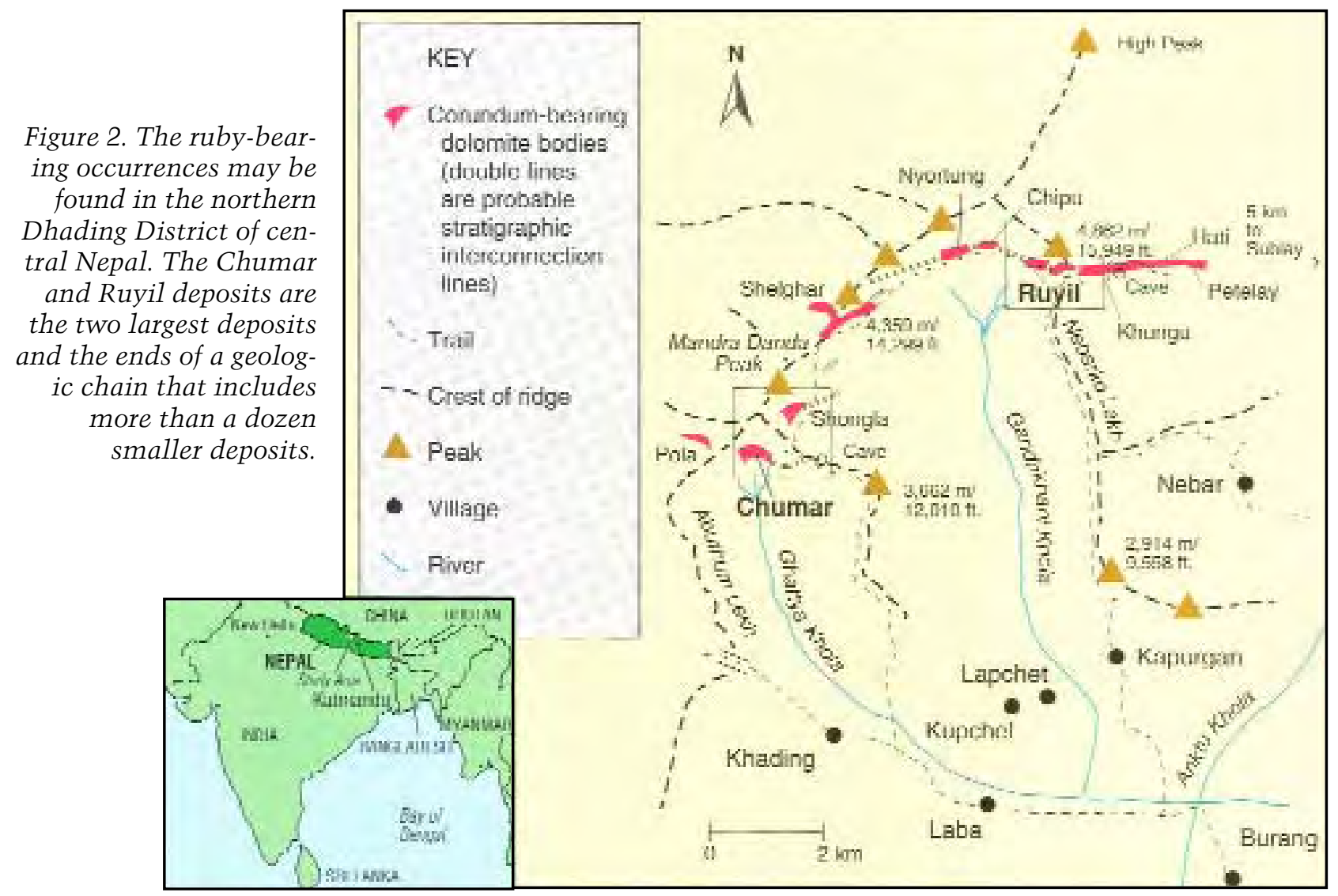

but they have not yet been mined. However, Chumar and Ruyil remain the most recognized deposits of commercial-grade and finer quality rubies and pink sapphires in Nepal.

One of the authors (AMB) was told that blue sapphires are currently being recovered from the Taplejung District of eastern Nepal. The authors have examined a few non-gem-quality specimens, but there is no additional information on the amount or quality of the material being unearthed. The claim holder reports, however, that the sapphire crystals occur in outcrops on the slopes of the mountain known as Sapphire Hill, approximately $1.5 \mathrm{~km}$ northwest of the small village called Khupatal, north of the Tamur River in the Taplejung District. Contrary to Baba's 1982 report, our investigations yielded no evidence that rubies have ever been found in this district.

The first in-depth study of ruby from Nepal was provided by Harding and Scarratt (1986). Soon after, researchers in Germany also described fancy-color (pink and violet) sapphires from unspecified deposits in Nepal (Kiefert and Schmetzer, 1986, 1987). A detailed investigation of one very fine gem-quality ruby from Nepal was reported in 1988 (Bank et al., 1988). Robinson et al. (1992) were the first to men- tion a specific deposit, named Chumar, for the corundum occurrences. Overviews on gems from Nepal also described corundum deposits (e.g., Niedermayr et al., 1993). The most recent observations on the internal features of this material were provided by Henn and Milisenda (1994). The present study supports the findings of these previous researchers, and adds both new characteristics and specific source information to these earlier reports.

\section{LOCATION AND ACCESS}

The corundum deposits occur on the southwest flank of the Ganesh Himal (a high mountain massif consisting of several major peaks clustered together), $68 \mathrm{~km}$ north-northwest of the capital city of Katmandu, and $40 \mathrm{~km}$ west of Trisuli Bazar. An overview of the region reveals rice paddies in the lowlands, with primarily corn and barley crops in the hills. Above approximately 1,830 m (6,000 feet), one finds forests of rhododendron trees, then grass, and, eventually, bare rock. The landscape at the deposits is that of extremely steep, cliff-like domes of dolomitic marble about $150 \mathrm{~m}$ (500 feet) high lying in lenticular bodies that are surrounded by steep slopes of schist. There are deeply entrenched, rocky gorges, choked with dense vegetation that 
reaches almost to the corundum deposits, which crop out in the dangerously craggy cliffs.

Travel to the deposits from Katmandu usually takes about six days. The trek begins with a circuitous bus ride from Katmandu to Trisuli Bazar, and then five days of rather strenuous hiking up the Ankhu River Valley and its tributaries. Travel to the deposits is hampered not only by the high elevations, remote locations, and rugged terrain, but also by the severe seasonal weather conditions. Winter snow usually covers the higher trails from midNovember to the end of April, and monsoons buffet the countryside from mid-June through September. Therefore, the best times to reach the deposits are usually from early May to mid-June and from early October to mid-November. A knowledgeable guide is essential.

Both the Chumar and Ruyil deposits lie within what was formerly known as the Laba Panchayat of the northern Dhading District, Bagmati Zone, in central Nepal (figure 2). The Chumar deposit lies at $28^{\circ} 13^{\prime} 20^{\prime \prime} \mathrm{N}, 84^{\circ} 58^{\prime} 52^{\prime \prime} \mathrm{E}$, at an altitude of $3,800 \mathrm{~m}$ $(12,500 \mathrm{feet})$; it is approximately $1.2 \mathrm{~km}$ south of the Mandra Danda mountain peak (elevation 4,358 $\mathrm{m} / 14,300$ feet), near the Tamang village of Burang. The Ruyil deposit lies about $6 \mathrm{~km}$ northeast of Chumar, at $28^{\circ} 15^{\prime} 05^{\prime \prime} \mathrm{N}, 85^{\circ} 02^{\prime} 07^{\prime \prime} \mathrm{E}$, and an elevation of about $4,200 \mathrm{~m}(13,800$ feet $)$.

\section{GEOLOGY AND OCCURRENCE}

The geology of Nepal is dominated by the Himalayan Mountains, which formed as a result of the collision between the northward-drifting Indian plate and the Asian plate starting about 30 to 50 million years ago. The initial line of collision /called the Indus Suture Zone) is now in Tibet. The Indian plate continued in a northward drift, pushing beneath the Asian plate, whereupon the Indian plate broke into northern and southern segments, as the southern segment was forced beneath the northern segment. This major structural breakage is known as the Main Central Thrust (MCT) and extends east-west, the full length of Nepal (figure 3). At least twice subsequently, the continuing northward drift of the Indian plate caused a major breakage along progressively younger and more southerly thrusts, known as the Mahabharat Thrust and the Main Boundary Thrust (MBT). Each continental slice was pushed beneath the higher and more northerly slices of the Indian plate to form the imbricate (shingle-like) stack that is responsible for the elevation of the Himalayan Mountains. Each of these various continental slices has a different lithology and grade of metamorphism; yet they are all roughly the same geologic age (Precambrian and lower Paleozoic), with the highest grade above the MCT and lower grades below the MCT (there is no metamorphism below the MBT). This sequence is inverted from what is normally encountered, because of the subduction thrusts.

The Ganesh Himal corundum occurs near the top of the lower-grade metasediments of the Nawakot Series (again, see figure 3), below the MCT. The gems are found in what was a limestone formation (the Malekhu Limestone, lower Paleozoic) that has

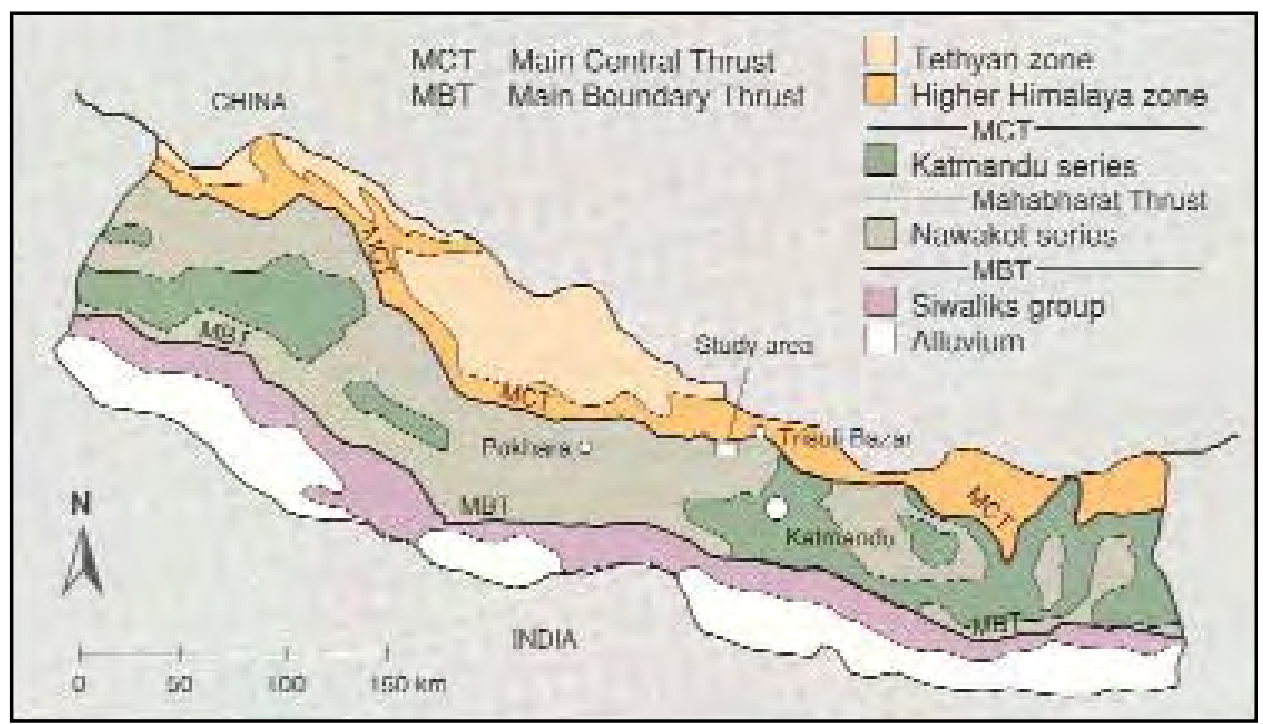

Figure 3. This simplified geotectonic map of Nepal indicates the main geologic structures (tectonic zones) and the main rock-forming series and groups in Nepal. The study area is near the top of the Nawakot series, below the MCT. Source: Mineral Resources Map of Nepal, United Nations publication, 1993. 


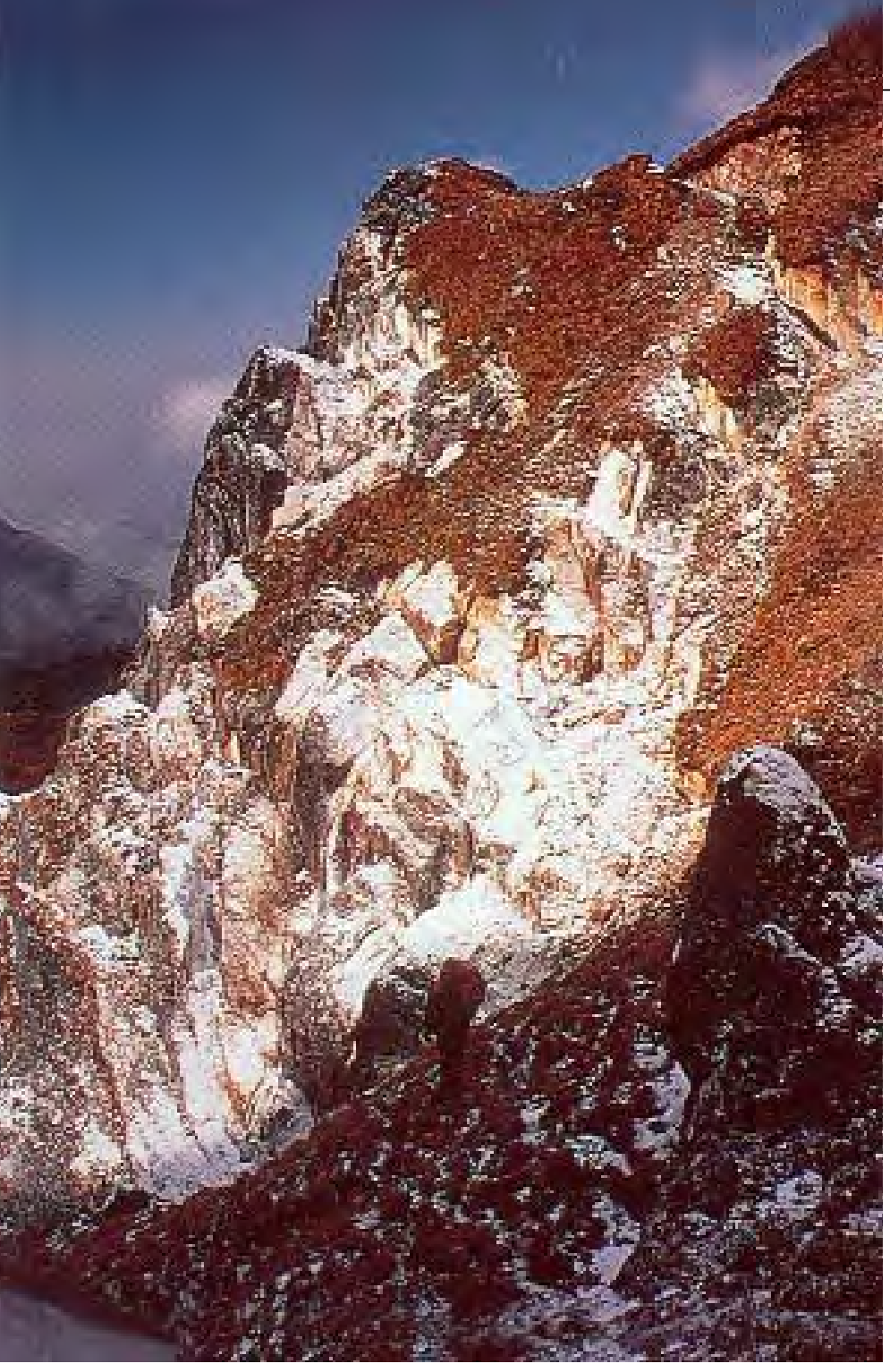

Figure 4. The remote Chumar ruby deposits are visible along the steep slopes of the Himalayas, where the white marble outcrops overlook the valley below. Photo by Ted Daeschler.

been converted to a dolomite marble because of its proximity to the tectonic forces of the MCT. This once-continuous dolomite marble layer has been torn into a dozen isolated bodies, about $1 \mathrm{~km}$ from one another. These dolomite bodies occur as thickened beds and isolated pods $60-150 \mathrm{~m}$ thick and up to a kilometer long. The bodies are separated by black schist with quartzite interlayers.

Within these isolated dolomite pods are mineral seams that were originally aluminous clay interlayers in the limestone,- these have been converted, again due to the intense shearing pressures of the MCT, into a suite of metamorphic minerals that includes corundum. Each seam has a slightly different suite of minerals, depending on variations in the original composition of the clay interlayers. In one notable variation (the Ruyil deposit), abundant graphite has formed, presumably due to a local abundance of marine organic material in the original interlayer. The dolomite marble host rock is consistent throughout the dozen pods.

At the western end of these dozen dolomite bodies, which extend for $15 \mathrm{~km}$, they are more distinctively pod-like lenses,- in the central section, the dolomite bodies are more like a thickened stratigraphic bed with parallel walls less than 100 $\mathrm{m}$ thick. The continuation eastward has not been explored in the very deep, densely forested chasms, but corundum is known to occur at the Sublay claim at the far eastern end. Of the dozen dolomite bodies, the westernmost four-Pola, Chumar, Shongla, and Shelghar-have produced corundum, only Ruyil in the central part, and only Sublay at the eastern end, are corundum bearing. Of these six corundum-bearing bodies, Chumar and Ruyil have been the most productive, with Shongla and Shelghar only recently developed and Pola and Sublay not yet consistently worked. This study focuses primarily on the Chumar and Ruyil deposits.

Chumar Deposit. First studied in 1984 by AMB, the Chumar deposit extends east-west for about $550 \mathrm{~m}$, with a central thickness of approximately $150 \mathrm{~m}$ (figure 4). At the west end, the dolomitic body is bounded by a sharp fault trending $\mathrm{N} 60^{\circ} \mathrm{W}$, dipping steeply to the northeast. The east end of the body tapers down to a tail, with no fault line at the boundary. Distinct bedding in the dolomite body, which now consists of large eroded domes, strikes east-west throughout all but the extremities, where it is bent to the northwest, creating a sigmoid shape. The seams, which are about $8 \mathrm{~m}$ apart and dip $32^{\circ}$, vary widely in thickness but average about $20 \mathrm{~cm}$; they are sometimes folded on a small scale.

Ruyil Deposit. The first studies of the Ruyil deposit were conducted in 1985 by AMB. This deposit extends east-west for approximately $128 \mathrm{~m}$, with a general thickness of $60 \mathrm{~m}$. The western portion of the dolomite body appears to end abruptly in a curved outline of shattered dolomite without distinct bedding; yet there is no discernible fault line. No corundum has been found in the continuous outcrops of bedded dolomite on the eastern side of this body. 


\section{ASSOCIATED MINERALS OF THE CORUNDUM DEPOSITS}

Six specimens of corundum in host rock from the Chumar mine (ranging from $2.3 \times 1.3 \times 1.8 \mathrm{~cm}$ to $7.3 \times$ $3.5 \times 4.6 \mathrm{~cm}$ ) were examined. We identified the seam material as primarily calcite and dolomite. Associated minerals include blue tabular blades of kyanite, small brownish orange euhedral crystals of rutile, different micas (stacked sheets of transparent green fuchsite, orange-brown phlogopite, and whitish margarite), and colorless apatite and scapolite, in addition to the violetish blue-to-red crystals of corundum (figure

5). One of the authors also identified brucite, tremolite, talc, pyrite, and sphalerite during his geologic studies at the Chumar mine (Bassett, 1985a). This list expands on the ones published previously; other researchers have additionally identified zoisite, epidote, muscovite, and anor-thite in mineral samples containing corundum from Nepal (Harding and Scarratt, 1986). Mineral specimens from this locality are often very colorful, with green fuchsite, orange phlogopite, blue kyanite, and red corundum, all occurring together in a white calcite matrix.

Rubies from the Ruyil deposit, unlike those from Chumar and the other deposits in Ganesh Himal, are embedded in abundant graphite with a less complete suite of associated minerals. In all other respects, though, they appear to be similar to the rubies from elsewhere in the district. Wel-formed gem-quality corundum crystals are more common from Ruyil than from Chumar.

\section{MINING METHODS}

The actual mining for gemstones is usually performed by local Tamang villagers using crowbars, picks, and shovels (figure 6), with occasional blasting. Blasting followed by hammering is used more commonly at the Chumar deposit than at Ruyil, and incline tunnels have been started at the latter deposit (Chakrabarti, 1994). All of the ruby and fancy-color sapphire deposits are primary (i.e., the stones are found in the host rock); no secondary deposits have been located to date. The miners usually excavate where the marble outcrops can be seen at the surface; the corundum itself is the prime indicator mineral for new deposits.

\section{PRODUCTION, QUALITY, AND SIZES}

It is very difficult to estimate how many tens of thousands of carats of corundum have been produced from these deposits over the past 15 years or so. Except for

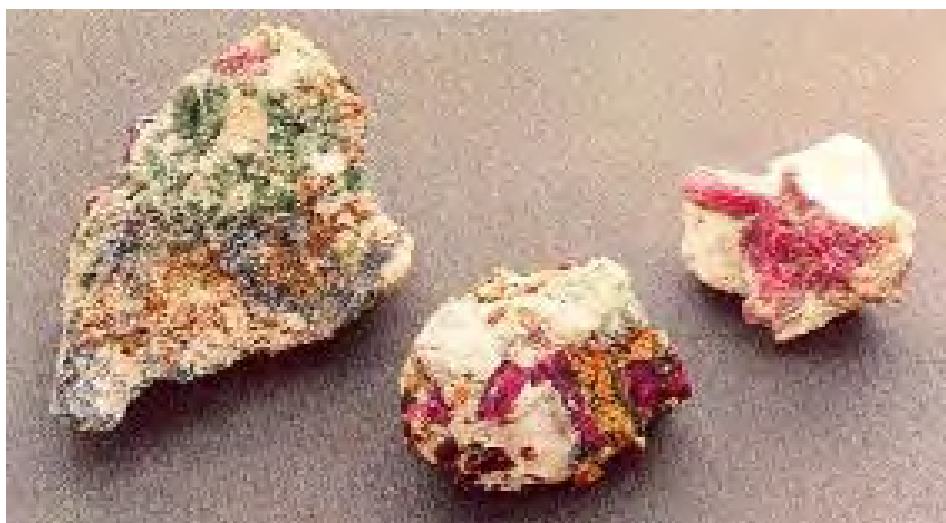

Figure 5. The Nepalese corundum deposits have an interesting assemblage of mineral occurrences, including tabular stacks of green fuchsite, orangebrown phlogopite, and colorless to white margarite micas, as well as blades of blue kyanite and dipyramidal forms of corundum in shades of red or pink (some containing large blue color zones). The host rock is white calcite and dolomite. Photo by Dr. H. A. Hänni.

the brief period that Himalayan Gems Nepal officially controlled the mining efforts, most mining has been unofficial and uncontrolled, so no

Figure 6. At the Chumar deposit, local farmers use basic hand tools to remove the corundum crystals from the host rock. Photo by Allen M. Bassett.

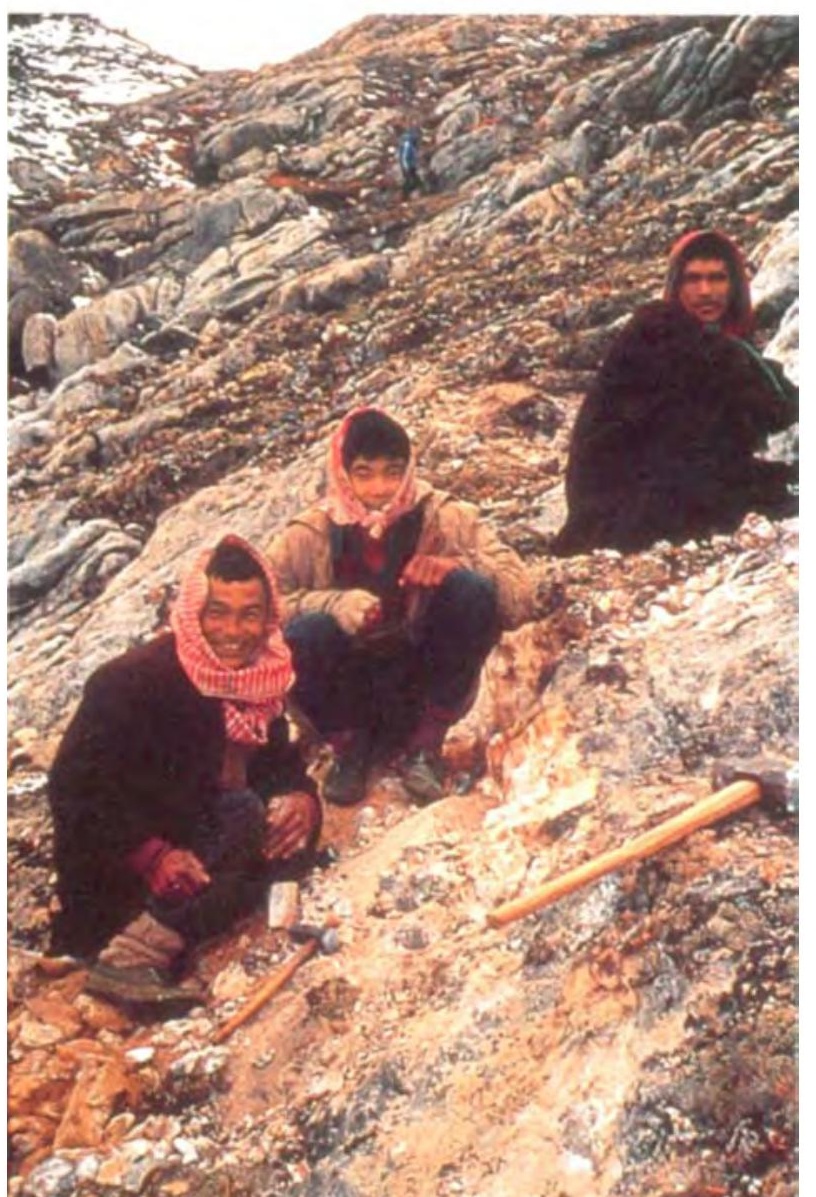


TABLE 1. Gemological characteristics of the rubies and fancy-color sapphires from Nepal.

\begin{tabular}{|c|c|c|}
\hline Propererties & No. samples & Observations \\
\hline Color & 27 polished & Ranging from red to pink to purplish pink, often with visible violetish blue color banding \\
\hline Clarity & $\begin{array}{l}27 \text { polished } \\
13 \text { crystals }\end{array}$ & Very clean to heavily included, most in the range slightly to heavily included \\
\hline Refractive & 20 faceted & $\mathrm{n}_{\mathrm{e}}=1.760-1.762$ \\
\hline \multirow[t]{2}{*}{ Index } & & $\mathrm{n}_{0}=1.769-1.770$ \\
\hline & 7 cabochon & $\mathrm{n}=1.76-1.77$ (spot method) \\
\hline Birefringence & 20 & $0.008-0.009$ \\
\hline Optic & 20 & uniaxial negative \\
\hline \multicolumn{3}{|l|}{ character } \\
\hline \multirow[t]{2}{*}{ Specific gravity } & 27 polished & $3.94-4.01$ \\
\hline & 13 crystals & \\
\hline \multirow[t]{2}{*}{ Pleochroism } & 27 & Moderate to strong dichroism \\
\hline & & $\begin{array}{l}\text { Red zones: yellowish orange to orangy red parallel to the c-axis, and reddish purple to purple-red, or } \\
\text { purplish pink to purple-pink, perpendicular to the c-axis } \\
\text { Violetish blue zones: greenish blue to blue parallel to the c-axis, and violetish blue to violet-blue per } \\
\text { pendicular to the c-axis. }\end{array}$ \\
\hline \multirow[t]{2}{*}{$\begin{array}{l}\text { UV } \\
\text { luminescence }\end{array}$} & 27 & $\begin{array}{l}\text { Red to pink zones. Long-wave }(365 \mathrm{~nm}) \text { : Moderate to very strong red Short-wave }(254 \mathrm{~nm}) \text { : } \\
\text { Faint to moderate red }\end{array}$ \\
\hline & & Violetish blue zones: Generally inert \\
\hline $\begin{array}{l}\text { Optical } \\
\text { absorption } \\
\text { spectrum (nm) }\end{array}$ & 27 & $\begin{array}{l}\text { General absorption up to approximately } 450 \mathrm{~nm}, 468 \text { (sharp, narrow), } 475 \mathrm{~nm} \text { (sharp, } \\
\text { weak to moderate), } 476 \mathrm{~nm} \text { (sharp, narrow), } 525-585 \mathrm{~nm} \text { (broad band), } 659 \mathrm{~nm} \text { (faint, nar } \\
\text { row), } 668 \mathrm{~nm} \text { (faint, narrow), } 675 \mathrm{~nm} \text { (very faint, narrow; when present), } 692 \mathrm{~nm} \text { (sharp, } \\
\text { narrow), } 694 \mathrm{~nm} \text { (sharp, narrow) }\end{array}$ \\
\hline \multirow[t]{3}{*}{ Internal features } & 27 & $\begin{array}{l}\text { Short rutile needles, various cloud patterns, stringer formations, strong color zoning, weak } \\
\text { to prominent growth structures, laminate twinning and parting, "fingerprints," negative } \\
\text { crystals and crystalline inclusions of (with elements identified and mode of identification } \\
\text { in parentheses): }\end{array}$ \\
\hline & & $\begin{array}{l}\text { margarite mica (AI, Si, Ca; SEM-EDS and XRD)a apatite (Ca, P; SEM-EDS, XRD and } \\
\text { Raman)a rutile (Ti; SEM-EDS) diaspore (XRD, Raman, and FTIR)a dolomite (Raman) }\end{array}$ \\
\hline & & $\begin{array}{l}\text { phlogopite mica (K, Mg, Al, Si, Fe; SEM-EDS and XRD)a calcite (Ca, C; SEM-EDS and } \\
\text { FTIR) uvite tourmaline (XRD) anorthite feldspar (Raman) boehmite (FTIR) }\end{array}$ \\
\hline
\end{tabular}

through near-infrared region (between 280 and 880 $\mathrm{nm}$ ) on 17 fashioned samples. For the region between 400 and 6000 wavenumbers $\left(\mathrm{cm}^{-1}\right)$, we used a PyeUnicam Fourier-transform infrared (FTIR) 9624 spectrometer with a diffuse reflectance unit for sample measurement. We performed a total of 49 analyses on different regions, color zones, and orientations of 27 samples. Energy-dispersive X-ray fluorescence (EDXRF) chemical analyses were performed on 25 samples (and on different color zones on some samples, for a total of 34 analyses) on a Spectrace TN5000 system, using a program specially developed by Prof. W. B. Stern for the semi-quantitative analysis of corundum. Prof. Stern's program uses chemically pure element standards and three spectra focusing on the light, medium, and heavy elements, so that the results can be interpreted to three decimal places (i.e., 0.001). He also used a beam condenser to measure small areas or zones of an individual stone. To analyze the internal growth structures of the pol- ished stones, we used a horizontal microscope, a specially designed stone holder, and a mini-goniometer attached to one of the oculars on the microscope, employing the methods described by Schmetzer (1986a and b), Kiefert and Schmetzer (1991), and Smith (1996). We analyzed more than 45 inclusions using a scanning electron microscope with an energy-dispersive X-ray spectrometer (SEM-EDS), X-ray diffraction analysis, and a Raman micro-spectrometer. Some of the inclusions were identified by a single method and others by a combination of techniques (see table 1).

\section{GEMOLOGICAL CHARACTERISTICS OF THE RUBIES AND FANCY-COLOR SAPPHIRES FROM NEPAL}

The data revealed no significant differences from one sample to the next-including those samples identified as originating from Chumar and Ruyil- 
in terms of standard gemological properties, crystal morphology, inclusion patterns, UV-Vis-NIR spectra, or chemical composition. Therefore, the complete data collected on all of the samplesthose with specific deposit designations, as well as those without-will be presented as a single group.

Crystal Morphology. The rough crystals were predominantly euhedral, with little or no evidence of chemical dissolution on their surfaces. Two main crystal forms dominate the morphology of the corundum found in Nepal (figure 9). The first are dipyramidal crystal habits composed of larger, dominant hexagonal dipyramid $z$ (2241) faces and smaller, subordinate basal pinacoid c (0001) and positive rhombohedron $\mathrm{r}$ (1011) faces. The second is a modification of this basic habit, where there is an addition of subordinate hexagonal dipyramid $n$ (2243) faces. Rarely, crystal forms consisting of dominant hexagonal dipyramid ? (llllllll 1428 3) faces, with subordinate c (0001), $r(1011)$, and occasionally $\mathrm{n}$ (2243) faces, were also encountered.

Many of the crystals had a blade-like appearance when viewed parallel to the c-axis (again, see figure 8). Groups of intergrown crystals were also frequently encountered.

Figure 9. Two crystal habits were most typical in the rabies and fancy-color sapphires from Nepal. (A) The primary crystal form was dominated by dipyramid z (2241) crystal faces, with more subordinate basal pinacoid c (0001) and positive rhombohedron $r$ (1011) crystal faces also present.

(B) This primary crystal form was frequently modified by subordinate to intermediate dipyramid n (2243) crystal faces.

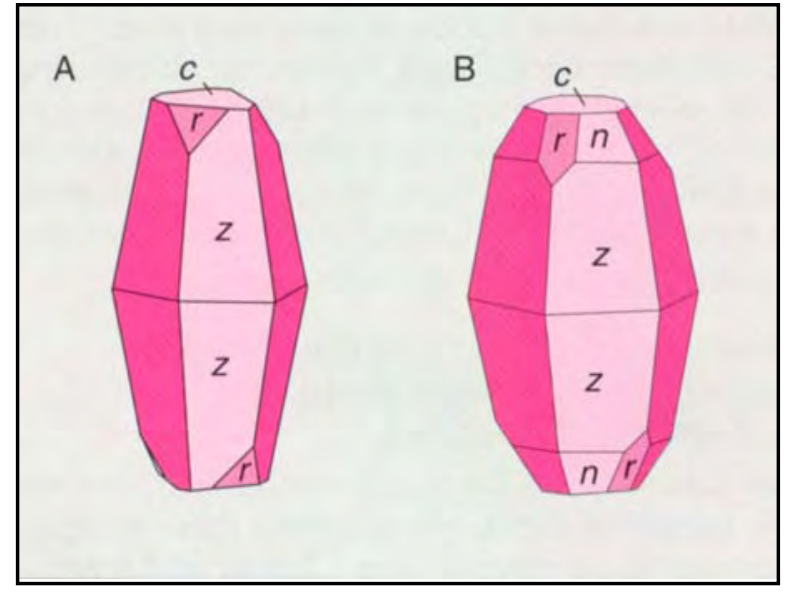

Visual Appearance. Face up, most of the polished samples ranged from a "pure" red or pink to a purplish pink. Both the rough and polished samples commonly had strong, eye-visible color zoning (see Growth Characteristics below). A few could even be better described as bicolored (red and very dark violetish blue) corundum; some had additional colorless or pink zones (figure 10). The diaphaneity of the crystals and polished samples ranged from transparent to translucent, depending on the nature and number of inclusions present, as well as on the color saturation and tone of the violetish blue zones.

Refractive Indices, Birefringence, Optic Character, and Specific Gravity. These standard gemological properties were found to be consistent with corundum in general (see, e.g., Webster, 1983; Liddicoat, 1989; Hughes, 1990; Hurlbut and Kammerling, 1991) and, more specifically, with the rubies and fancycolor sapphires from Nepal described by past researchers (Harding and Scarratt, 1986; Kiefert and Schmetzer, 1986, 1987; Henn and Milisenda, 1994; see table 1).

Reaction to Ultraviolet Radiation. The various color zones of the sample corundums had different reactions to UV radiation. The red to pink zones fluoresced red to both long-wave (moderate to very strong intensity) and short-wave (faint to moderate intensity) UV. The dark violetish blue zones were generally inert to both long- and short-wave UV radiation.

Pleochroism. All samples exhibited moderate to strong dichroism when viewed perpendicular to the caxis with a dichroscope. Within the red-to-pink color zones, we observed yellowish orange to orangy red or pink parallel to the c-axis and reddish purple to purple-red or purplish pink to purple-pink (i.e., for rubies or pink sapphires, respectively) perpendicular to the caxis. In the dark violetish blue color zones, we noted greenish blue to blue parallel to the c-axis and violetish blue to violet-blue perpendicular to the c-axis.

Growth Characteristics. Internal Growth Structures. Weak-to-prominent growth structures were seen in essentially all the polished gemstones examined. Most common were straight and angular sequences of the dipyramid $z$ planes (figure 11). Less common were sequences of the dipyramids $n$ or ?, as well as the basal pinacoid $c$ and the positive rhombohedron $r$. 
Observation of the gem perpendicular to the c-axis often enabled us to trace the progression of crystalhabit formation (figure 12).

Color Zoning. Chemical fluctuations in the growth environment produced obvious color zoning in most of the samples examined. Oscillations between consecutive periods of crystal growth, as well as a preferential crystallographic orientation of the colorcausing mechanisms $\mathrm{Cr}^{3}+$ (ruby) or $\mathrm{Fe}^{2}+$ ? $\mathrm{Ti}^{4}+$ (blue sapphire), are responsible for the inhomo-geneity of color observed in the samples (also refer to UV-VisNIR Spectroscopy). When the color was not homogeneous, red-to-pink and near-colorless zones were typically noted parallel to the dipyramid $z$ planes, whereas the dark violetish blue zones were concentrated along the dipyramid $z, n$, or ? planes, in addition to the positive rhombohedron $r$ (again, see figure 12).

The most distinctive color-zoning characteristics were related to the dark violetish blue zones. The dark appearance of these zones is attributed to the presence of red (i.e., chromium) and blue (i.e., iron and titanium) chromophores in the same growth phases. These color zones could be very narrow or very thick; the latter were observed only parallel to the dipyramid $z$ planes (see figures 11 and 13). They also appeared as distinct "wedges" cutting into the gemstone or even dominating it to the point of a bicolor (again, see figure 13). In these zones, we also observed a texture that might best be described as wispy or smoke-like. In some samples, an irregular color concentration had an undulating nature that resulted from near-colorless areas, or halos, surrounding very small, black-appearing mineral grains of presumably rutile (figure 14). In the case of rutile (TiO2) inclusions, Ti would be absorbed from the host corundum, thereby depleting an essential component of the Fe2+ ?Ti4+ charge-transfer necessary for the blue coloration..

Twinning. We saw twinning parallel to the positive rhombohedron $\mathrm{r}$ (1011) in several of the stones. Typically, we noted only one direction of laminated twinning, parallel to a single series of $\mathrm{r}$ (1011) planes; occasionally, however, there were as many as three twinning systems, parallel to additional positive rhombohedral planes. Parting parallel to $r$ (1011) was also prominent in a few samples (figure $15)$.

Inclusions. A rich diversity of inclusions were noted in the sample rubies and fancy-color sapphire.

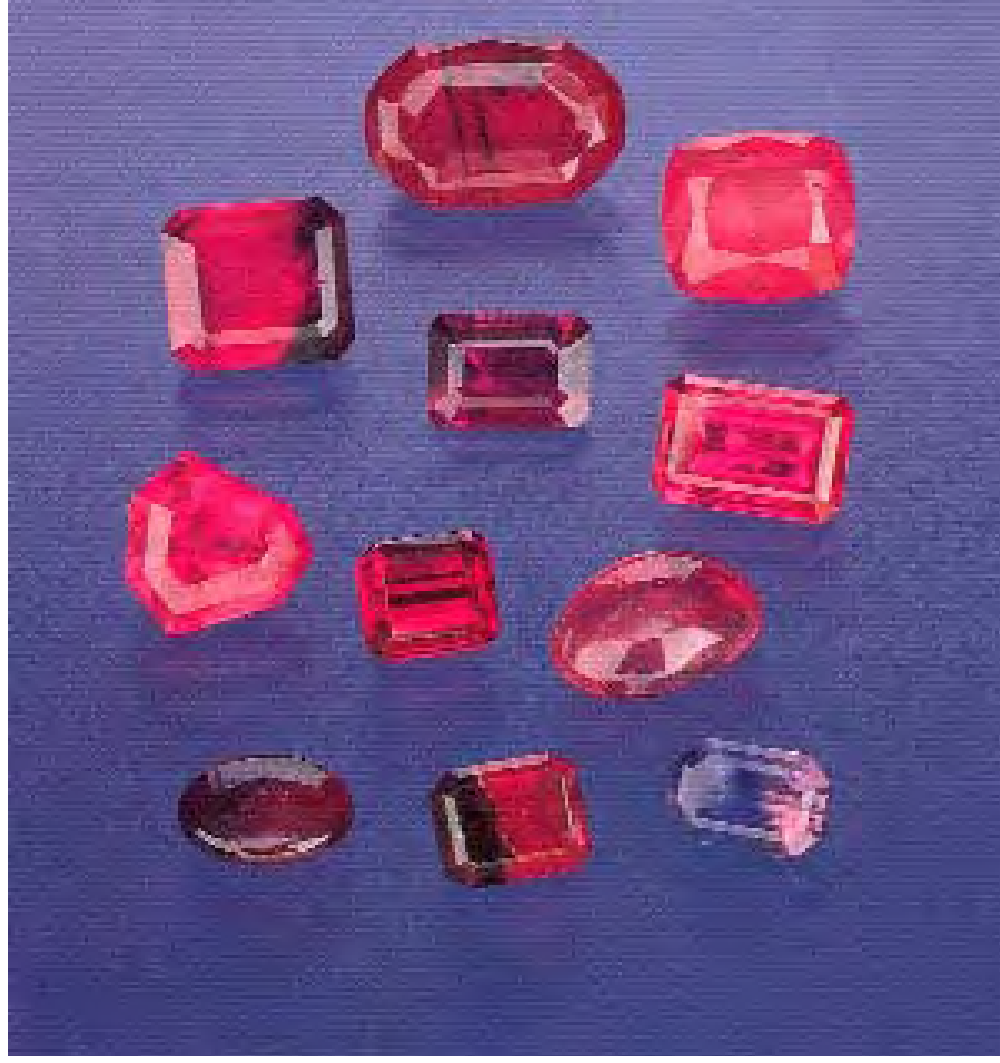

Figure 10. A wide range of gem-quality rubies and fancy-color sapphires have been recovered from Nepal. Distinctly bicolored-red or pink and violetish blue-stones illustrate some of the unusual zoning in this material. The non-heattreated Nepalese rubies and sapphires shown here range from 0.87 to $3.86 \mathrm{ct}$. Photo by Shane F. McClure.

Figure 11. Weak to prominent internal growth structures were frequently observed in the sample rubies and sapphires. This $4.81 \mathrm{ct}$ ruby reveals moderate zonal structures parallel to two series of dipyramid $z$ (2241) planes, along with distinct blue color banding. Immersion, magnified $8 \times$.

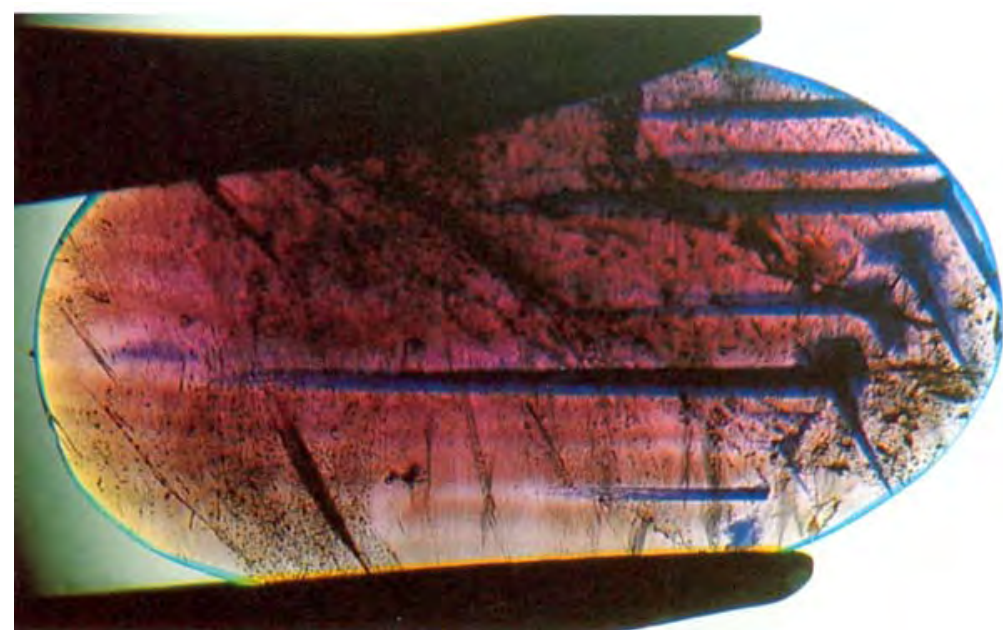




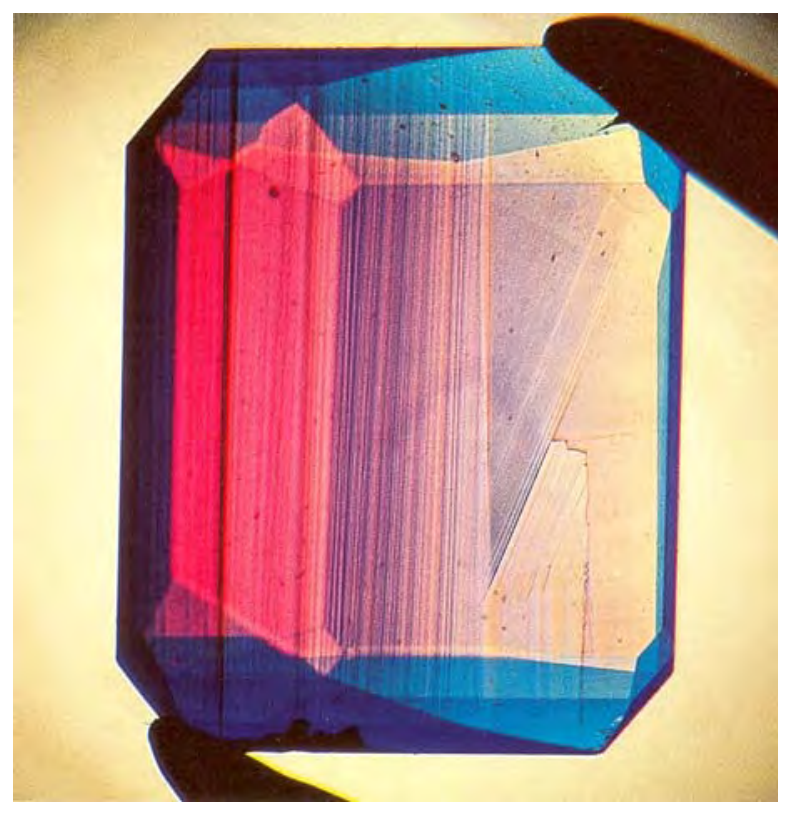

Figure 12. When viewed perpendicular to the $c$ axis, several samples revealed a great deal about the sequence of crystallographic growth. This Nepalese ruby shows a crystal habit composed of the basal pinacoid $c$ (the faint horizontal growth planes), the dipyramid $n$ (the angled growth planes), and the dipyramid $z$ (the vertical growth planes). Immersion, magnified 12x.

Most commonly, clouds of very fine, short rutile needles, present throughout, gave some of the gemstones a slightly "hazy" appearance to the unaided eye (figure 16). Bright orange-to-black crystals of rutile were observed singly or in small

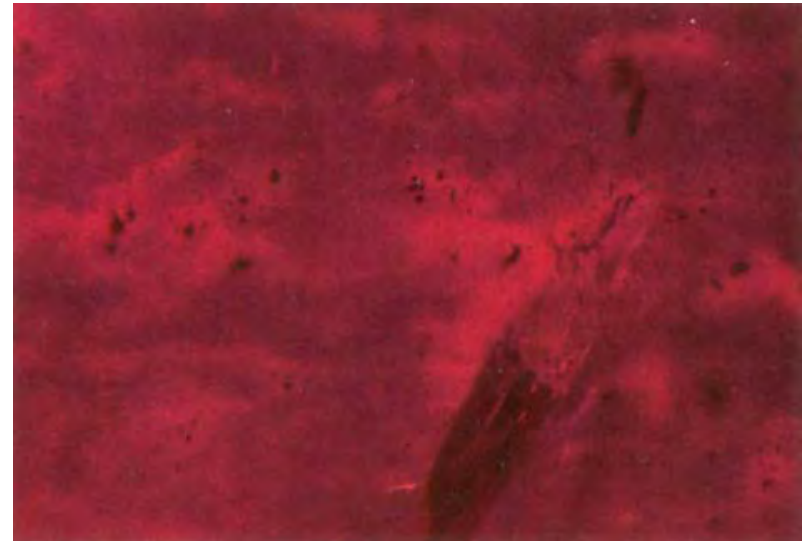

Figure 14. Some Nepalese rubies revealed irregular blue color zones that had paler patches or halos. At 66x magnification, it can be seen that these halos actually surround small mineral grains of what are presumed to be rutile. Darkfield illumination; photomicrograph by Edward f. Gübelin.

irregular clusters (figure 17); these displayed a metallic luster when they were polished at the surface. Other stringer-type inclusion patterns consisted of nearly parallel, slightly diverging "sprays," extending essentially perpendicular to growth planes or in an antenna-like pattern (figure 18).

Apatite took on a variety of forms, including euhedral hexagonal columns (figure 19, left) and slightly curved rods (figure 19, right). Although not commonly noted in apatite, basal cleavage was

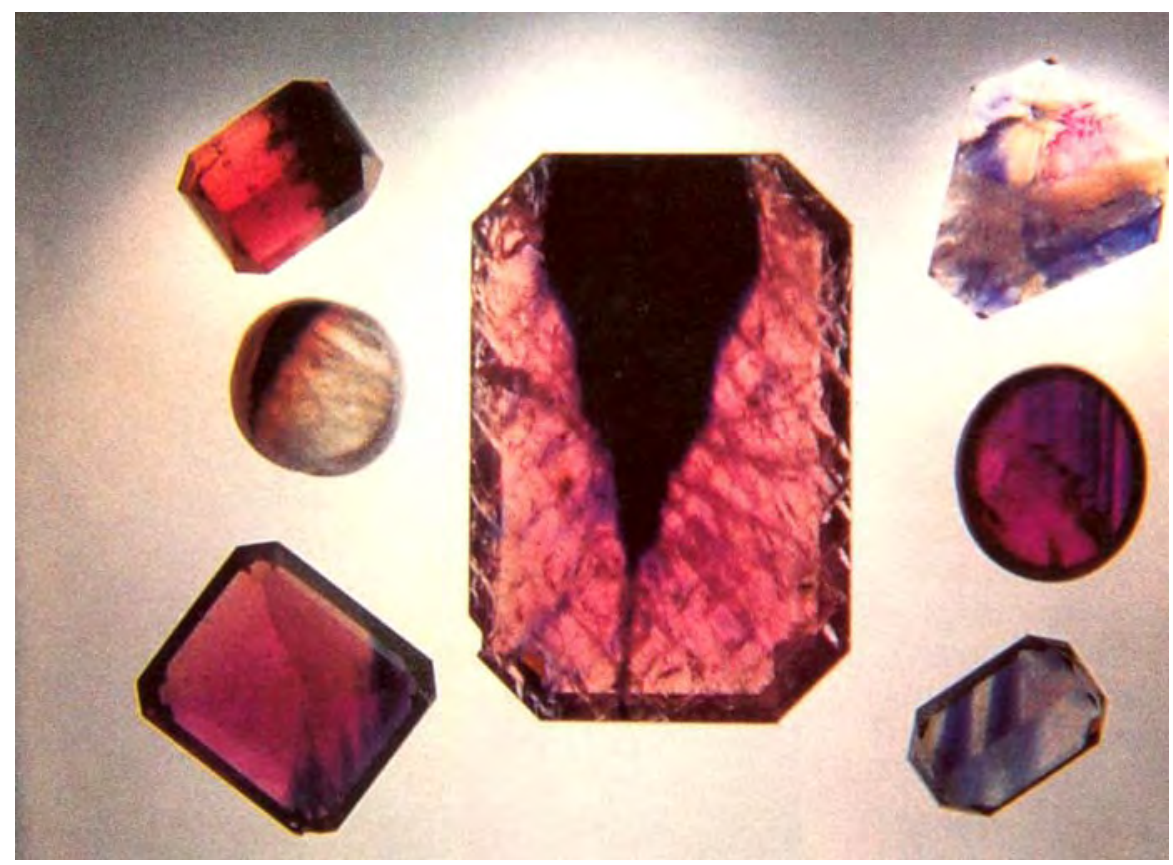

Figure 13. Distinct color zoning was present in most of the sample rubies and sapphires from Nepal. Colorless, red/pink, and dark violetish blue zones filled large sections of the stones, traversed them in bands, or appeared as large wedge-like forms. Such colorzoning characteristics gave many of the gemstones a bicolored appearance. 


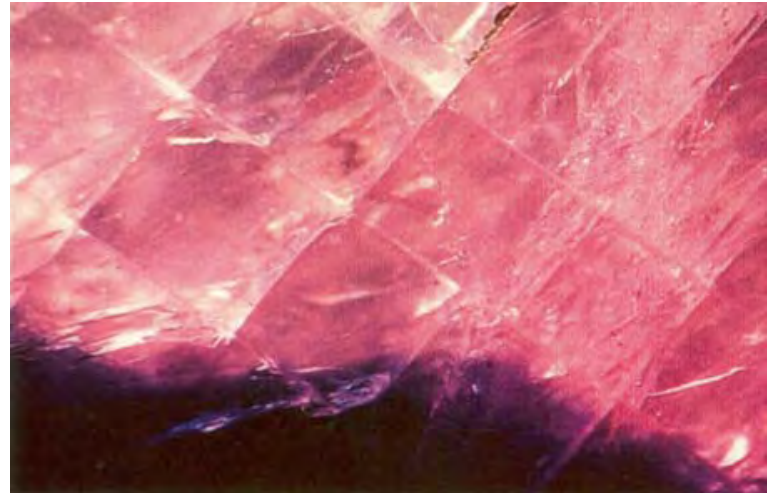

Figure 15. Parting planes parallel to one, two, or three series of positive rhombohedron $r$ (1011) crystal faces, were seen in a few samples. In this stone, the parting planes-which form a checkerboard pattern-were lined with the aluminum oxy-hydroxide boehmite, AIO(OH). Fiber-optic illumination, magnified 20x.

observed in several of the apatites we identified, especially in the rod-shaped forms. The calciumrich mica margarite was often present in irregular masses within which additional inclusions were noted, such as individual crystals of apatite or rutile, or masses of graphite, sometimes forming one complex mineral assemblage (figure 20). Light brown crystals of phlogopite mica occurred in small, mostly irregular, rounded forms (figure 21). Transparent colorless crystals of calcite and dolomite were seen infrequently (most of the transparent colorless crystals in these stones proved to be apatite or margarite). Although rare, black uvite tourmaline (figure 22) and transparent colorless anorthite feldspar (figure 23) were identified. Also

Figure 17. Clusters of small rutile crystals were also common in the rubies from Nepal. Typically, they were bright orange to black and displayed a metallic luster where polished at the surface. Fiber-optic illumination, magnified 50x.

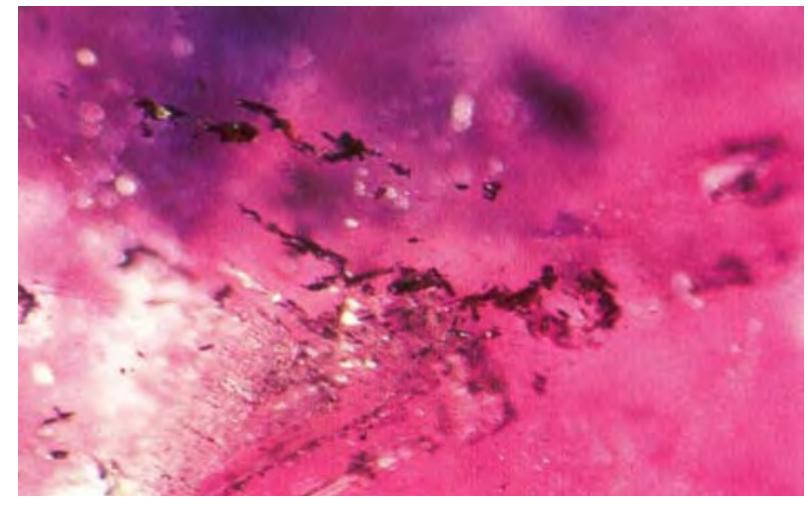

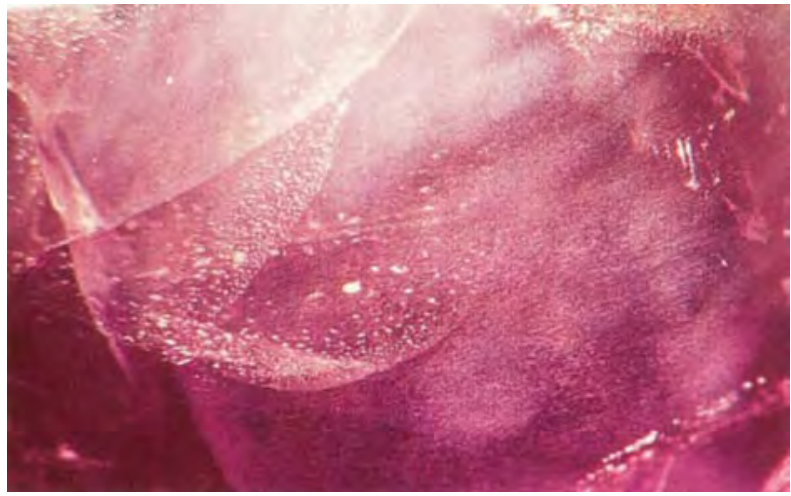

Figure 16. Clouds of very fine, short rutile needles were present in nearly all of the rubies and fancycolor sapphires from Nepal. However, none of these stones revealed the nest-like concentrations that are typical of rubies from Mogok. Fiber-optic illumination, magnified 22x.

unusual was the "halo" of minute rutile needles surrounding an unidentified small black mineral grain (figure 24).

We observed a wide range of fingerprint-like inclusions, all involved in various stages of the "healing" process. Two-phase (liquid and gas) inclusions were common. "Intersection tubules" at the junction of two or three twin planes were frequently penetrated by alteration products such as boehmite. Boehmite was also identified lining the parting planes. Irregular "veins" of $\mathrm{AlO}(\mathrm{OH})$-mostly boehmite, but also diaspore-were also noted traversing several of the polished gemstones. In reflected light, the reduced luster of the $\mathrm{AlO}(\mathrm{OH})$ "vein," as compared to the higher luster of the host corundum, could be mistaken for the glass-like

Figure 18. Antenna-hke stringer formations were frequently seen in the Nepalese samples. Although such inclusions have been noted in rubies from Luc Yen (Vietnam) and Mong Hsu (Myanmar), they tended to be more densely concentrated in the Nepalese samples. Fiber-optic illumination, magnified $32 x$.

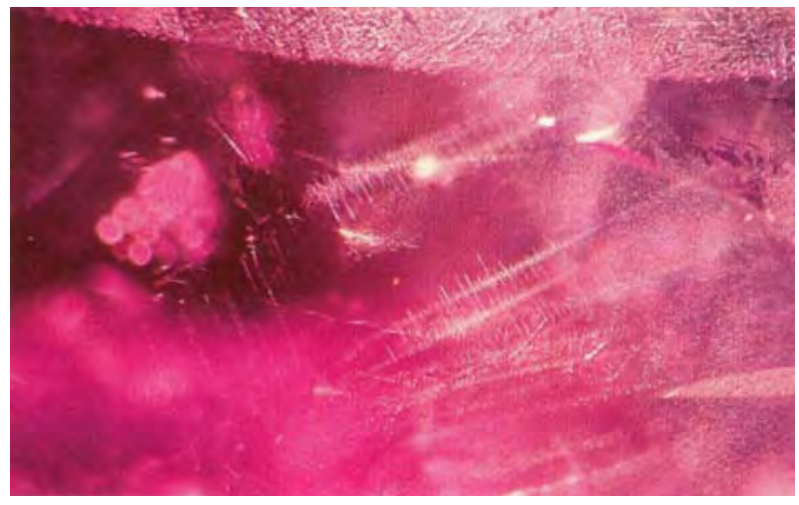



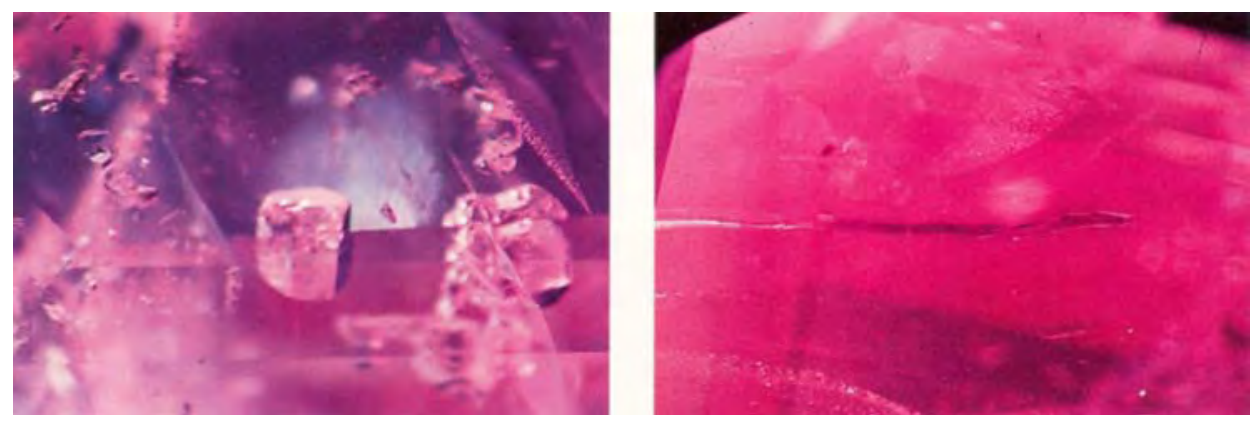

Figure 19. Common in the Nepalese samples, apatite took on several forms, including euhedral, hexagonal columns (left, magnified $50 \times$ ) and slightly curved "rods" (right, 32x). In most cases, these inclusions displayed basal cleavage, a property infrequently seen in apatite. Fiber-optic illumination.

fillings observed in some heat-treated rubies, but careful examination will establish that the gem has not been heated.

Absorption Spectra. All spectra were dominated by $\mathrm{Cr}^{3}+$ absorption features, with the bands being weaker in the lighter red (i.e., pinkish) stones and more intense in the deeper red stones. Occasionally a secondary absorption influence was seen as a result of the $\mathrm{Fe}^{2}+$ ? $\mathrm{Ti}^{4}+$ intervalence charge transfer responsible for the blue color component in the dark violetish blue zones. These results are consistent with those reported earlier by Kiefert and Schmetzer(1986, 1987).

Desk-Model Spectroscope. In the visible range, a general absorption to approximately $450 \mathrm{~nm}$ was apparent, along with weak to distinct lines at 468

Figure 20. Complex inclusion assemblages presented some intriguing identification challenges. In this Nepalese ruby, a large mass of the calcium-rich mica margarite ( $M)$ played host to other mineral inclusions of its own. The larger, granular-appearing mass proved to be a graphite and margarite combination $(G / M)$, while several of the brighter spots were identified as apatite (A) and rutile (R). SEM photo courtesy of SUVA, Lucerne, Switzerland.

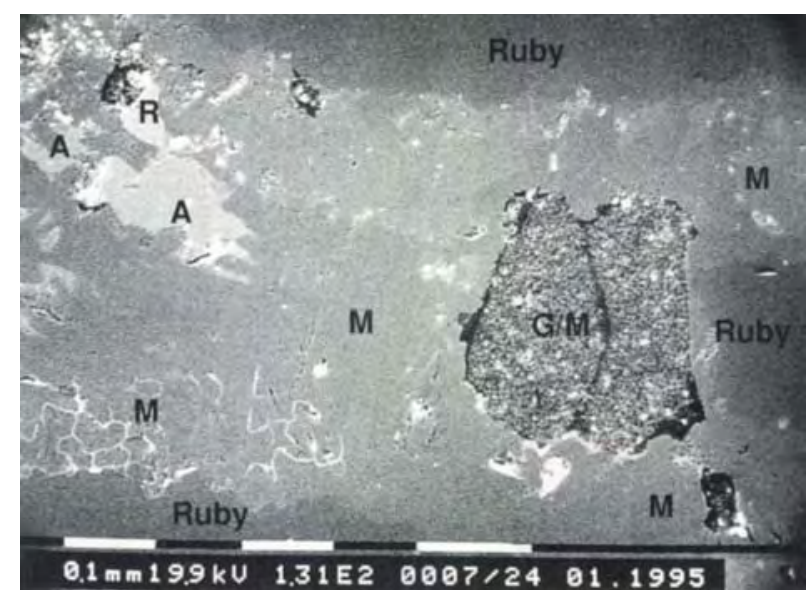

$\mathrm{nm}$ and at 475 and $476 \mathrm{~nm}$ (a doublet). The width of a moderate-to-distinct absorption band from approximately 525 to $585 \mathrm{~nm}$ was related to the chromium content of the gemstone. We also noted faint lines at 659 and $668 \mathrm{~nm}$, plus two strong lines at 692 and 694 $\mathrm{nm}$, which appear as a bright emission line at $693 \mathrm{~nm}$.

UV-Vis-NIR Spectroscopy. The general shape of the spectral curve also varied considerably depending on the chromium content of the zones measured. The two broad bands at about 405 and $550 \mathrm{~nm}$, as well as the weak to distinct sharp peaks recorded at 468,475 , 476, 659, 668, 692 and 694, are all ascribed to $\mathrm{Cr}^{3}+$. A faint absorption peak observed at $675 \mathrm{~nm}$ in some stones has also been recorded in rubies from other sources (e.g., Mong Hsu, Myanmar, and certain deposits in east Africa), but the cause is still unclear (Peretti et al., 1995).

Infrared Spectroscopy. In addition to the dominant absorption characteristics of corundum, between 300 and $1000 \mathrm{~cm}^{-1}$ (peak positions at about 760, 642, 602, and $450 \mathrm{~cm}^{-1}$; Wefers and Bell, 1972), the rubies

Figure 21. Predominantly small, rounded light brown crystals of phlogopite mica also were seen frequently in the Nepalese rubies. Fiber-optic illumination, magnified $45 x$.

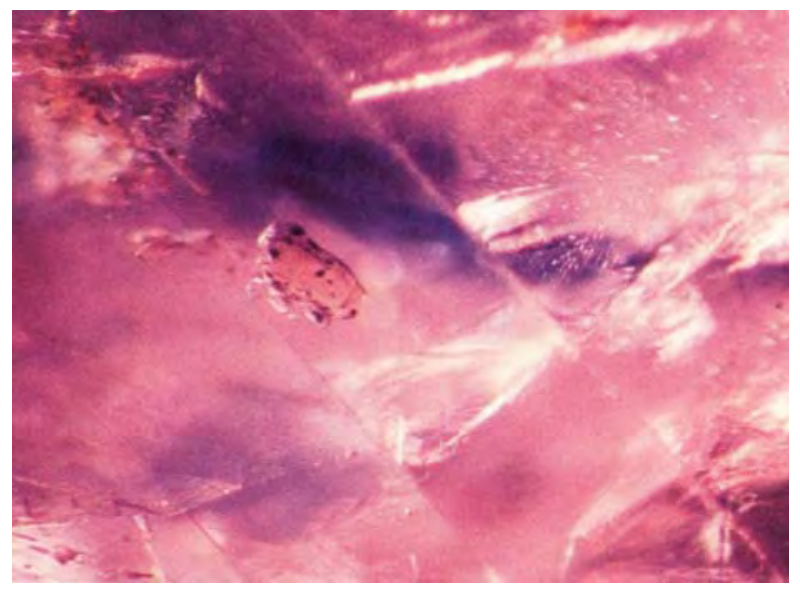




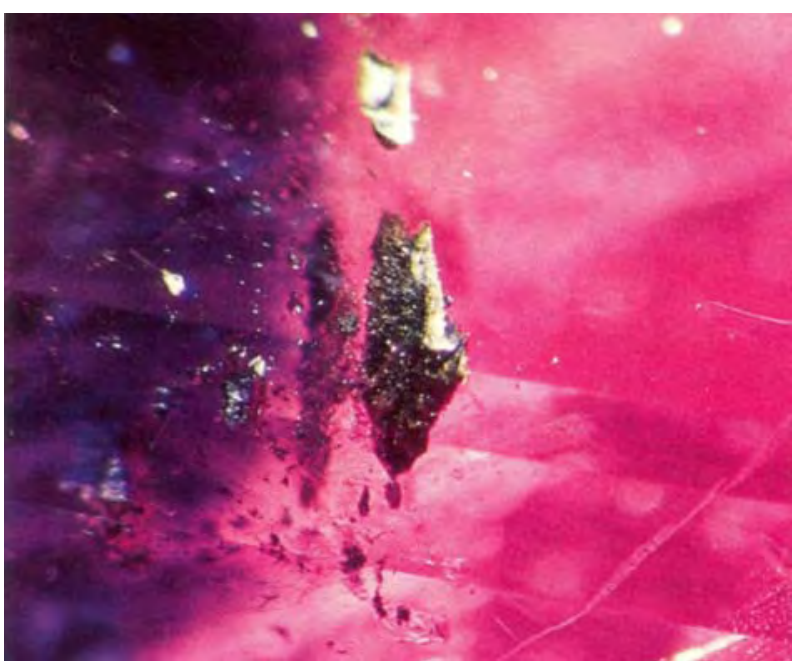

Figure 22. A series of unusual granular masses were identified as uvite tourmaline, which has not been documented as an inclusion in rubies from any other source. It thus provides a useful indication of Nepalese origin. Fiber-optic illumination, magnified $35 \times$.

and sapphires in this study revealed two dominant bands at about $3320 \mathrm{~cm}^{-1}$ and $3085 \mathrm{cnr}^{-1}$, with an additional pair of weaker bands at 2100 and 1980 cm"1 (figure 25). These absorption bands are related to $\mathrm{OH}$ stretching frequencies and identify the presence of boehmite (Farmer, 1974; Wefers and Misra, 1987). Although different color zones did not reveal any statistical differences in the presence or absence of boehmite, different areas and orientations of the same stone did show variations in the absolute and relative intensities of the absorption bands, as well as a slight shift in the position of the absorption maximum. To a much lesser degree, diaspore was also indicated in the infrared spectra of some samples, with bands at approximately 1990, 2040, 2885, and $3025 \mathrm{~cm}^{-1}$ (Farmer, 1974; Wefers and Misra, 1987; Smith, 1995).

The presence of $\mathrm{AlO}(\mathrm{OH})$-boehmite and diaspore-was generally traced to locations along parting planes or irregular seams. Not all samples showed $\mathrm{AlO}(\mathrm{OH})$-related absorption bands, while several displayed such strong $\mathrm{AlO}(\mathrm{OH})$ absorption features that a distinction between boehmite and diaspore was not possible. Absorption bands associated with mica and calcite were also occasionally recorded.

Chemical Analysis. The most significant variations were recorded in $\mathrm{Cr}$ concentration, which again correlated to the depth of red-to-pink color in the area measured. Titanium $(\mathrm{Ti})$ and iron $(\mathrm{Fe})$ were

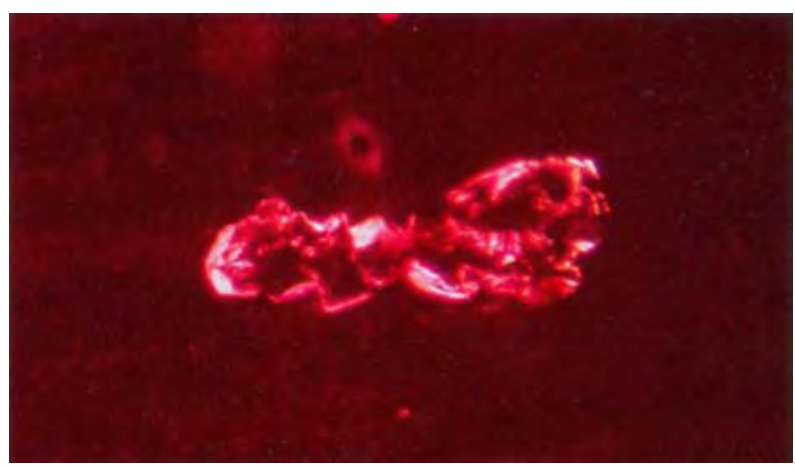

Figure 23. Raman micro-spectroscopy identified this mineral aggregate in a Nepalese ruby as anorthite feldspar. This is the first report of this mineral in ruby from any source. Photomicrograph by Edward I. Gübelin; darkfield illumination, magnified 66x.

the next most significant trace elements recorded, followed by measurable amounts of vanadium (V) and gallium $(\mathrm{Ga})$, as shown in table 2 .

One interesting observation related to the traceelement concentrations of areas that were "pure" red as opposed to ones that were "pure" dark violetish blue. In every instance, the concentrations in absolute and relative values showed no consistent variation between $\mathrm{Cr}$, Fe, or $\mathrm{Ti}$ within the two color zones.

\section{DISCUSSION}

Corundum from Nepal has received sporadic mention in the gemological literature over the past decade or so (see, e.g., Harding and Scarratt, 1986; Kiefert and Schmetzer, 1986 and 1987; Bank et al., 1988; Niedermayr et al., 1993). The results of this current investigation support and expand on the findings of such earlier researchers and, for the first time, provide detailed locality information. We identified three inclusions in the rubies from Nepal that had not been described before-uvite tourmaline, anorthite feldspar, and diaspore-as well as several distinctive inclusion and color-zoning patterns. However, we did not observe the three-phase inclusions described by Kiefert and Schmetzer (1986, 1987 ) in any of our samples. Also, we did not encounter the identification difficulties experienced by Bank et al. (1988); that is, all of our samples were easily identified as natural corundum.

In general, the rubies and fancy-color sapphires from Nepal are similar to corundum from other marble-type sources found around the world, including Myanmar (Burma), Vietnam, Afghanistan, Pakistan, and Tanzania. The most distinctive features of these Nepalese corundums are their inclusions. 


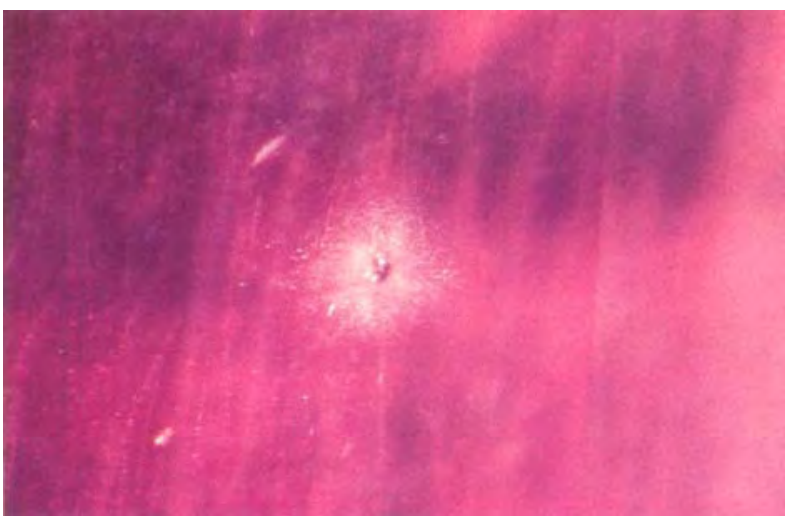

Figure 24. Still another feature that has not been noted in rubies from other sources was present in many of the rubies and fancy-color sapphires from Nepal: small black mineral grains surrounded by halos of very fine, minute rutile needles. Fiberoptic illumination, magnified 50x.

The dense concentrations of very fine, short rutile needles are unlike the long, highly iridescent rutile needles observed in most rubies from marble-type deposits. Dense "nests" of short rutile needles, so typical of rubies from the historic Mogok stone tract in upper Myanmar, were not seen in our Nepalese study samples. The various stringer patterns we saw in these Nepalese stones have also been seen in rubies from other deposits, including Mong Hsu in Myanmar (Smith and Surdez, 1994; Peretti et al., 1995) and Vietnam (Kane et al., 1991; Smith, 1996). However, the Nepalese stones appeared to have much denser concentrations of such patterns.

Apatite crystals of various forms may be seen in rubies from many sources, including Mogok (e.g., Gübelin and Koivula, 1986), Vietnam (Kane et al., 1991), and various deposits in East Africa. However, the rod-shaped apatites observed in the samples from Nepal have not been described in rubies or fancy-color sapphires from any other source. Kane et al. (1991) described similar transparent colorless rod-shaped minerals in rubies from Vietnam, but these were identified as calcite. A common mineral inclusion in rubies from marbletype deposits, calcite was encountered only rarely in the rubies from Nepal.

Mica is common in corundum from other deposits (e.g., Myanmar, Sri Lanka, and Tanzania), but the sheer number of inclusions of the variety margarite in our test samples is unlike anything we have seen in rubies from other sources. Anorthite feldspar and uvite tourmaline, which were observed in a few of our sample rubies and fancy-color sapphires, have not been identified in rubies from any other locality. Therefore, they may also be instrumental in establishing Nepalese origin. Nor have the authors seen inclusion patterns such as the small black mineral surrounded by a spherical "halo" of minute rutile needles in rubies from other sources. On the other hand, inclusions such as pyrrhotite, zircon, pyrite, and spinel have not been identified to date in rubies from Nepal; these are frequently seen in rubies from East Africa, Vietnam, and Myanmar, as well as other sources.

In their natural (not heat-treated) state, these rubies, pink sapphires, and bicolored sapphires should not be difficult to distinguish from rubies, including those with blue color zones, from other sources. No heat-treatment studies were conducted on these samples. However, when such stones are heat treated, the inclusion features and color zoning will be greatly altered, making it more difficult to identify corundum from Nepal (see, e.g., Peretti et al., 1995). Although it is usually difficult to detect a gemstone's source by the inclusion features, observation of any of the above-described mineral inclusions will clearly separate a natural ruby or fancycolor sapphire from a synthetic counterpart produced by any of the known manufacturing processes.

The linear and angular sequences of non-colorzoned growth structures in our samples-following the crystal planes $z, n, ?, r$, and $c$ - did not reveal any unique or diagnostic features or patterns. Similar sequences of growth structures have been observed by one of the authors (CPS) in natural rubies from other sources (e.g., Vietnam or East Africa). However, they can be useful in separating

TABLE 2. Semi-quantitative EDXRF chemical analyses of majorto-trace elements in the rubies and fancy-color sapphires from Nepal.

\begin{tabular}{ll}
\hline Oxide & \multicolumn{1}{c}{$\mathrm{Wt} . \%$} \\
\hline $\mathrm{Al}_{2} \mathrm{O}_{3}$ & $98.9-99.8$ \\
$\mathrm{Cr}_{2} \mathrm{O}_{3}$ & $0.013-0.383$ \\
$\mathrm{TiO}_{2}$ & $0.016-0.224$ \\
$\mathrm{Fe}_{2} \mathrm{O}_{3}$ & $0.004-0.069$ \\
$\mathrm{~V}_{2} \mathrm{O}_{5}$ & $0.004-0.034$ \\
$\mathrm{Ga}_{2} \mathrm{O}_{3}$ & $0.010-0.023$ \\
\hline
\end{tabular}




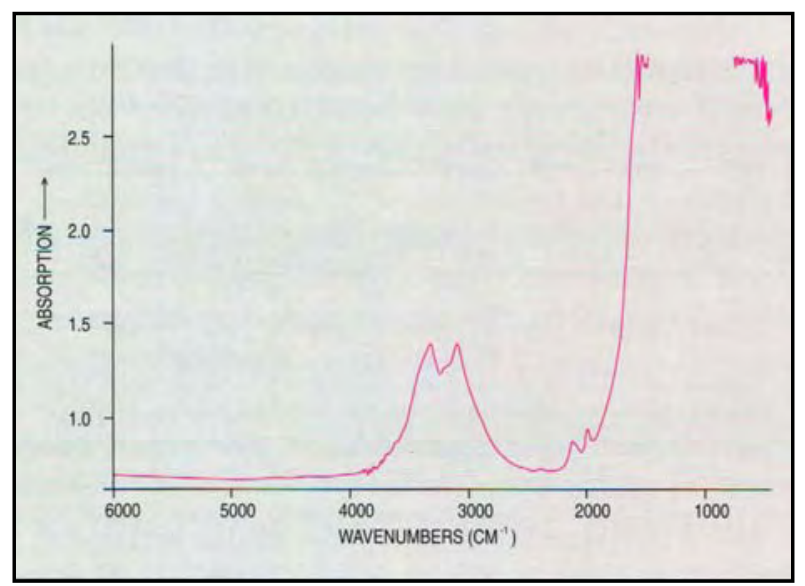

Figure 25. The non-heat-treated rubies and fancycolor sapphires from Nepal revealed additional absorption features in the infrared region of the spectrum. Distinct absorption bands at 3320 and $3085 \mathrm{~cm}^{-1}$, and weaker peaks at 2100 and $1980 \mathrm{~cm}^{-1}$, indicated the presence of boehmite, which was seen concentrated along veins or lining parting planes. Such absorption characteristics are helpful not only in identifying foreign mineral phases that may be present, but also for indicating that the gem has not been heat treated.

natural from synthetic rubies (Schmetzer, 1986a and b; Kiefert and Schmetzer, 1991; Smith, 1996). Kiefert and Schmetzer $(1986,1987)$ also identified growth planes consisting of the second-order hexagonal prism a (1120) and hexagonal dipyramid $v$ (4481). Bank et al. (1988) described an unusual sequence with these two growth planes that also was not encountered during our study. This unusual sequence appears to relate directly to the blade-like forms of some rough crystals. Our samples did not reveal any "swirled" growth structures, such as those seen in rubies from Mogok (e.g., Gübelin and Koivula, 1986) or Vietnam (Kane et al., 1991). Nor did they have centralized "cores," such as those present in rubies from Mong Hsu (Smith and Surdez, 1994; Peretti et al., 1995).

Blue color zones and color banding have been noted in rubies from several sources, including Afghanistan (Bowersox, 1985; Bowersox and Chamberlin, 1995), Myanmar (Mong Hsu: Smith and Surdez, 1994; Kammerling et al., 1994; Smith, 1995; Peretti et al., 1995), Vietnam (Kane et al., 1991), as well as Sri Lanka and Tanzania (Tunduru), by one of the authors (CPS). However, the blue color zones and banding in Nepal rubies have some distinctive characteristics. These include the successions of straight and angular, thin-to-thick bands parallel to the dipyramid $z$ (2241) planes; the large red and dark violetish blue zones (i.e., bicolored stones); the "wedge-shaped" color zones,- and the wispy to smoke-like textures observed in the color bands and "halos" of nonblue zoning surrounding mineral inclusions.

Chemically, these rubies and fancy-color sapphires are also similar to their counterparts from other marble-type sources (Tang et al., 1988; Hughes, 1990). Nevertheless, their chemistry will provide a ready means of separating them from high-iron natural rubies from sources such as Thailand (Tang et al., 1988), Cambodia (Jobbins and Berrange, 1981), Madagascar (Smith, 1996), and certain deposits in East Africa (see, e.g., Hänni and Schmetzer, 1991). In addition, the collection of chemical data is also valuable in separating natural from synthetic corundum (e.g., Stern and Hänni, 1982; Muhlmeister and Devouard, 1991).

Infrared spectroscopy may provide additional proof that the gemstone was not heat treated, when $\mathrm{AlO}(\mathrm{OH})$ is present, as well as a very good indication of whether it is natural or synthetic (Volynets et al., 1972; Beran, 1991; Smith, 1995, pp. 326-328). One of the authors (CPS) has observed that rubies from other natural sources, such as certain deposits in Vietnam or East Africa, sometimes also reveal dominant absorption features relating to boehmite, as well as other minerals.

No consistent variations were noted in the samples from Chumar as compared to those from Ruyil, with respect to their standard gemological properties, UV-Vis-NIR and FTIR spectral characteristics, crystal morphology, chemical make-up, or the inclusions identified. One inclusion feature, however, that may indicate that a ruby came from the Ruyil mine is the presence of graphite (in association with certain mineral inclusions), which appears to be much more prevalent in the corundum from this deposit.

It is interesting to note that "trapiche" corundum, with six "arms" extending from a central core, has been found at the Ruyil deposit (figure 26). Trapiche-like rubies and pink sapphires have been reported from Vietnam and Mong Hsu (Müllenmeister, 1995; Schmetzer et al., 1996). However, the arms in the Nepalese samples are very different in composition-predominantly phlogopite, apatite, calcite, and graphite-from that identified in samples from other sources. 


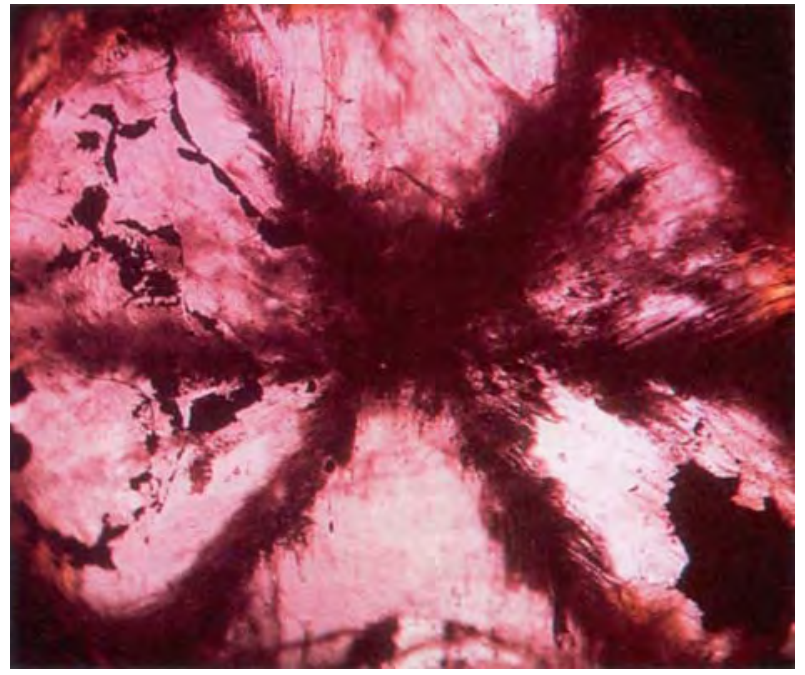

Figure 26. Reminiscent of trapiche emeralds, $a$ very small number of rubies from the Ruyil deposit display a series of rays that intersect at the center of the crystal, along the three-fold axis and parallel to the prism crystal faces. Each ray consists of a linear concentration primarily of phlogopite, apatite, calcite, and graphite. Such unusual forms of "trapiche" corundum have also been recovered from Vietnam and Myanmar. Photo by Eva Strauss-Paillard.

\section{CONCLUSION}

In recent years, a number of ruby and sapphire deposits have been discovered in a wide variety of sources around the world. While Nepal is neither the newest nor most significant corundum source in the trade today, it offers an interesting array of ruby and fancy-color sapphires for jewelers, gemologists, and consumers alike. These gems from the Ganesh Himal appear to be concentrated along a single geologic "belt" within the northern Dhading District of east-central Nepal, and in two mines in particular, Chumar and Ruyil. Since they were first discovered in the early 1980s, these gemstones have been entering the world markets. The isolated locations, high altitudes, harsh seasonal weather conditions, and other difficulties have contributed to the sporadic mining activities and the relatively small amounts of gem material produced to date. However, research by two of the authors (MNM and $A M B$ ) indicates that larger reserves of these rubies and fancy-color sapphires are yet to be discovered. Modernized mining equipment and methods (including tunneling or "benching" techniques) will be necessary for these deposits to reach their full potential.
Although similar in general to rubies and fancycolor sapphires from other marble-type deposits, the Nepal corundums may be distinguished on the basis of the entire collection of the gem's individual properties and characteristics. Certain features that may prove helpful in the identification include dense concentrations of very fine, short rutile needles throughout the stone; rod-shaped forms of apatite; masses of transparent colorless margarite,-opaque black masses of uvite tourmaline; transparent colorless anorthite feldspar; and small black mineral grains surrounded by "halos" of minute rutile needles. Nepal may also be indicated for a particular ruby if any of the transparent mineral inclusions are associated with black masses of graphite. Nepal rubies and fancy-color sapphires may also have distinctive color-zoning characteristics, such as large red and dark violetish blue portions in a single stone (i.e., bicolor), or dark violetish blue zones in thick bands or wedge shapes. Especially distinctive is the presence of a wispy or smoke-like texture or near-colorless "halos" surrounding a mineral inclusion.

Such an ensemble of internal features also will help separate a Nepalese corundum from a synthetic corundum of any of the various production techniques. As a reminder, even in the remotest regions of the world, one should never take for granted that a gemstone is natural, as the synthetic ruby crystal fragment purchased in Nepal by one of the authors (MNM) illustrates.

Nepal's mineral wealth-consisting of tourmaline, beryl, garnet, quartz, spinel, danburite, kyanite, apatite, sodalite, zircon, sphalerite, epidote, diopside, iolite, and andalusite, among others-is already recognized widely in the trade. Now rubies, pink sapphires, and bicolored corundum can also be added to the list.

Acknowledgments: The authors are grateful to Dr. L. Kiefert and Dr. H. A. Hänni of the Swiss Gemmological Institute (SSEF), Basel, Switzerland, for performing Raman spectral analyses; to Dr. H.-D. Von Schulz of SUVA, Lucerne, Switzerland, for performing scanning electron microscopic analyses; to Professor S. Graeser of the Institute of Mineralogy and Petrography, University of Basel, for X-ray diffraction analyses; and to Prof. W. B. Stern of the Institute of Mineralogy and Petrography, University of Basel, Switzerland and Ms. N. Surdez of the Gübelin Gemmological Laboratory, Lucerne, for providing the semi-quantitative chemical analyses. Unless otherwise noted, photomicrographs are by Christopher P. Smith. 


\section{REFERENCES}

Baba T. (1982) A gemstone trip to Nepal. Gemmological Review, Vol. 4, No. 12, pp. 2-5.

Bank H.; Gübelin E., Harding H.H., Henn U., Scarratt K., Schmctzer K. (1988) An unusual ruby from Nepal. Journal of Gemmology, Vol. 21, No. 4, pp. 222-226.

Bassett A.M. (1979) Hunting for gemstones in the Himalayas of Nepal. Lapidary Journal, Vol. 33, No. 7, pp. 1492-1520.

Bassett A.M. (1984) Rubies in the Himalayas of Nepal. Report submitted to the Nepal Department of Mines and Geology, Katmandu, 19 pp.

Bassett A.M. (1985a) Application for mining license. Submitted to the Nepal Department of Mines and Geology, Katmandu, 14 pp. Bassett A.M. (1985b) The tourmalines of Nepal. Mineralogical Record, Vol. 16, No. 5, pp. 413-418.

Bassett A.M. (1987) Nepal gem tourmalines. Journal of Nepal Geological Society, Vol. 4, No. 1-2, pp. 31-41.

Beran A. (1991) Trace hydrogen in Verneuil-grown corundum and its colour varieties-an IR spectroscopic study. European Journal of Mineralogy, Vol. 3, pp. 971-975.

Bowersox G.W. (1985) A status report on gemstones from Afghanistan. Gems ↔ Gemology, Vol. 21, No. 4, pp. 192-204.

Bowersox G.W., Chamberlin B.E. (1995) Gemstones of Afghanistan. Geoscience Press, Tucson, AZ.

Chakrabarti C.K. (1994) A preliminary report on the Ganesh Himal ruby occurrences. Submitted to the Nepal Department of Mines and Geology, Katmandu, 8 pp.

Farmer V.C. (1974) The infrared spectra of minerals. Mineralogical Society Monograph 4, Mineralogical Society, London.

Gübelin E.J., Koivula J.I. (1986) Photoatlas of Inclusions in Gemstones. ABC Edition, Zurich, Switzerland.

Hänni H.A., Schmetzer K. (1991) New rubies from the Morogoro area, Tanzania. Gems ↔ Gemology, Vol. 27, No. 3, pp. 156-167.

Harding R.R., Scarratt K. (1986) A description of ruby from Nepal. Journal of Gemmology, Vol. 20, No. 1, pp. 3-10.

Henn U., Milisenda C.C. (1994) A microscopical study of Nepalese ruby and sapphire. Journal of the Gemmological Association of Hong Kong, Vol. 17, pp. 82-84.

Hughes R.W. (1990) Corundum, 1st ed. Butterworths Gem Books, Butterworth-Heinemann, London.

Hurlbut C.S., Kammerling R.C. (1991) Gemology, 2nd ed. Wiley Interscience, New York.

Jobbins E.A., Berrangé J.P. (1981) The Pailin ruby and sapphire gemfield, Cambodia. Journal of Gemmology, Vol. 17, No. 8 pp. 555-567.

Kammerling R.C, Scarratt K., Bosshart G., Jobbins E.A., Kane R.E., Gübelin E.J., Levinson A.A. (1994) Myanmar and its gems-An update. Journal of Gemmology, Vol. 24, No. 1, pp. $3-40$.

Kane R.E., McClure S.F., Kammerling R.C, Khoa N.D., Mora C, Repetto S., Khai N.D., Koivula J.I. (1991) Rubies and fancy sapphires from Vietnam. Gems $\oplus$ Gemology, Vol. 27, No. 3, pp. 136-155.

Kiefert L., Schmetzer K. (1986) Rosafarbene und violette Sapphire aus Nepal. Zeitschrift der Deutschen Gemmologischen Gesellschaft, Vol. 35, pp. 113-125.

Kiefert L., Schmetzer K. (1987) Pink and violet sapphires from Nepal. Australian Gemmologist, Vol. 16, No. 6, pp. 225-230.
Kiefert L., Schmetzer K. (1991) The microscopic determination of structural properties for the characterization of optical uniaxial natural and synthetic gemstones, part 1: General considerations and description of the methods. Journal of Gemmology, Vol. 22, No. 6, pp. 344-354.

Liddicoat R.T. (1989) Handbook of Gem Identification, 12th ed. Gemological Institute of America, Santa Monica, CA

Muhlmeister S., Dcvouard B. (1991) Determining the natural or synthetic origin of rubies using energy-dispersive X-ray fluorescence (EDXRF). In A.S. Keller, Ed., Proceedings of the International Gemological Symposium, Gemological Institute of America, Santa Monica, CA, pp. 139-140.

Müllenmeister H.J. (1995) Ein Trapiche-Rubin aus Myanmar (Burma). Lapis, Vol. 12, No. 95, pp. 50.

Niedermayr G., Brandstätter P., Hammer V.M.F. (1993) Edelund Schmucksteinvorkommen in Nepal. Zeitschrift der Deutschen Gemmologischen Gesellschaft, Vol. 42, No. 2-3, pp. 69-89.

Peretti A., Schmetzer K., Bernhardt H.J., Mouawad F. (1995) Rubies from Mong Hsu. Gems ↔ Gemology, Vol. 31, No. 1, pp. 2-26.

Robinson G.W., King V.T., Asselbom E., Cureton F., Tschernich R., Sielecki R. (1992) What's new in minerals? Mineralogical Record, Vol. 23, No. 5, pp. 423-437.

Schmetzer K. (1986a) An improved sample holder and its use in the distinction of natural and synthetic ruby as well as natural and synthetic amethyst. Journal of Gemmology, Vol. 20, No. 1, pp. 20-33.

Schmetzer K. (1986b) Natürliche und synthetische RubineEigenschaften und Bestimmung. Schweizerbart, Stuttgart, Germany.

Schmetzer K., Hänni H.A., Bernhardt H-J., Schwartz D. (1996) Trapiche rubies. Gems ↔ Gemology, Vol. 32, No. 4, pp. 242-250.

Smith C.P., Surdez N. (1994) The Mong Hsu ruby: A new type of Burmese ruby. JewelSiam, Vol. 4, No. 6, pp. 82-98.

Smith C.P. (1995) Contribution to the nature of the infrared spectrum for Mong Hsu rubies. Journal of Gemmology, Vol. 24, No. 5, pp. 321-335.

Smith C.P. (1996) Introduction to analyzing internal growth structures: Identification of the negative $\mathrm{d}$ plane in natural ruby. Gems $\oplus$ Gemology, Vol. 32, No. 3, pp. 170-184.

Stern W.B., Hänni H.A. (1982) Energy dispersive X-ray spectrometry: a non-destructive tool in gemmology. Journal of Gemmology, Vol. 18, No. 4, pp. 285-296.

Tang S.M., Tang S.H., Tay H.S., Retty A.T. (1988) Analysis of Burmese and Thai rubies by PIXE. Applied Spectroscopy, Vol. 42, No. 1, pp. 44-18.

Volynets F.K., Sidrova E.A., Stsepuro N.A. (1972) OH-groups in corundum crystals which were grown with the Verneuil technique. Journal of Applied Spectroscopy, Vol. 17, pp. 1088-1091

Webster R. (1983) Gems: Their Sources, Descriptions and Identification, 4th ed. Butterworths, London.

Wefers K., Bell G.M. (1972) Oxides and Hydroxides of Alumina, Alcoa Research Laboratories Technical Paper No. 19. Alcoa Research Laboratories, St. Louis, MO.

Wefers K., Misra C. (1987) Oxides and Hydroxides of Alumina, Alcoa Research Laboratories Technical Paper No. 19, Revised. Alcoa Research Laboratories, St. Louis, MO. 